\title{
Optimization of an efficient rapid regeneration of Indian wheat cultivars by callus induction and multiple shoot induction using mature embryos
}

\author{
R. Krishnaveni ${ }^{1,2 *}$, D. P. Biradar ${ }^{1}$, I. S. Katageri ${ }^{1}$ and S. Shuba ${ }^{1}$ \\ ${ }^{1}$ University of Agricultural Sciences, Dharwad, India \\ ${ }^{2}$ Vijayanagara Sri Krishnadevaraya University, Ballari-583105, Karnataka, India \\ *Corresponding author
}

A B S T R A C T

\section{Keywords}

Callus induction, multiple shoot induction, Indian wheat, mature embryos

Article Info

Accepted:

15 November 2019

Available Online:

10 December 2019
Wheat is the second most produced staple food crop in world. An efficient method for in vitro micro propagation and genetic transformation of wheat are crucial for both basic and applied research. The present study was initiated with a view to develop a regeneration system in 4 genotypes of wheat cultivars HD2888, HD2329, DBW148, and DBW88 as a prerequisite to transformation. The mature embryos were excised from seeds and cultured on MS medium supplemented with high and low concentrations of cytokinins and auxins respectively. Callus induction was prominent with 4mg/L 2,4D with HD2888. The regeneration system was optimised and was prominent with $1 \mathrm{mg} / \mathrm{L}$ kinetin by slowly reducing the concentration of $2,4 \mathrm{D}$ to $2 \mathrm{mg} / \mathrm{L}$. The MS medium containing $2 \mathrm{mg} / \mathrm{L} \mathrm{N6}$-benzylaminopurine (BAP) and 0.5mg/L 2,4-D was found to be effective for multiple shoot formation in HD2932 cultivar that could produce 7 shoots per explants. The elongated shoots were separated and successfully rooted on half MS medium containing $0.2 \mathrm{mg} / \mathrm{L}$ indole-3-acetic acid (IAA) Callus mediated regeneration took approximately 36 days to regenerate where as multile shoot mediated regeneration took 20 days. Further studies will be taken up to check the transformation efficiency by transforming the desired gene through Agrobacterium mediated protocols.

\section{Introduction}

Abiotic and biotic stress are the major factors that are affecting the yield and nutritional quality of the crops especially wheat. Wheat is the second most produced staple food crop and india has the largest growing area of 31.47 million hectares and is the second largest producer of 86.53 million metric tons in the world. Global climate change is the important cause for yield loss in wheat. Hence, breaking the yield barrier and enhancing the abiotic stress tolerance are important goals of wheat improvement programs. Functional genomics of wheat is necessary to achieve these goals and requires availability of an efficient 
transformation and regeneration protocol (Ali sarali et al 2013).

Wheat is considered as a recalcitrant crop. Due to this nature, several explants of wheat have been used for their regeneration and transformation capacity, including the immature embryos (Rakesh K et al 2017), mature embryos (Ali sarali et al 2013), shoot apical meristem (Ahmad et al. 2002), scutellar tissue (Becker et al. 1994), microspores (Ziemienowicz et al. 2012), protoplasts (Ahmed and Sági 1993), inflorescence (Barro et al.1999) and leaf base (Haliloglu 2006). Immature embryos and inflorescence are the most frequently used explants due to their higher regeneration efficiency (Ziemienowicz 2014). Callus-mediated regeneration using mature and immature embryos explants have been reported (Rakesh K et al 2017). A good and efficient callus induction system in wheat highly depends on sterilization process, type of explants, genotypes, media composition and its $\mathrm{pH}$, growth hormones, inducers and incubation conditions (Mamrutha et al. 2014).Mature embryos are available throughout the year whereas immature embryos are available only during 12-20 days post-anthesis limiting their application for in vitro culture and genetic transformation readily.

Most frequently used auxin to induce callus in wheat is 2,4-dichlorophenoxyacetic acid $(2,4-$ D), a synthetic auxin and potent herbicide, at a concentration of $1-2 \mathrm{mg} / \mathrm{l}$. It is followed by dicamba (Ren et al. 2010) and picloram (Satyavathi et al. 2004). Till date, many regeneration media were optimized by adding cytokinins such as kinetin, 6benzylaminopurine (BAP), thidiazuron (TDZ), zeatin along with auxins indole-3-acetic acid (IAA), 1-naphthaleneacetic acid (NAA), 2,4D, picloram (Benderradji et al. 2012). Additionally, some inducers, such as $\mathrm{CuSO} 4$, AgNO3, were found to be useful to enhance the regeneration rate (Yu et al. 2008).
Genetic engineering opens opportunities to meet these challenges and allows introduction of novel desirable genes into host plants for the development of desired trait. However, efficient and rapid in-vitro regeneration is prerequisite for wheat improvement through genetic engineering and functional genomics approaches. Hence we reported a simple methodology for successful in vitro regeneration of wheat from mature embryos, developed based on combination of different growth regulators in four different wheat genotypes both by indirect callus mediated and direct multiple shoot induction mediated protocols.

\section{Materials and Methods}

\section{Plant materials}

Seeds of four wheat genotypes used for comparison of regeneration efficiency in this study, namely HD2888, HD2932, DWB148, DWB88 were obtained from AICRP, MARS, University of Agricultural sciences, Dharwad.

\section{In vitro germination and explant excision}

Mature embryos were used as explants for in vitro culture. Seeds were pre treated with $70 \%$ alcohol for 2 min followed by 3 to 5 rinses with sterile distilled water. The seeds were then surface sterilized with $4 \%$ sodium hypochlorite $(\mathrm{v} / \mathrm{v})$ with intermittent shaking for 15 minutes followed by 8 rinses with sterile distilled water. Seeds were then soaked overnight in sterile distilled water and embryos were excised from these imbibed seeds. The radical portion of mature embryo was slightly damaged and cultured with scutellum in contact with the medium to start initiation of callus.

\section{Callus induction}

Excised embryos were inoculated on petri 
plates containing MS medium supplemented with $30 \mathrm{~g} / 1$ sucrose, $3 \mathrm{mg} / \mathrm{l}$ casein hydrolysate and $3 \mathrm{mg} / \mathrm{l}$ proline (Ali sarali et al 2013) on four different concentrations ranging from 1-6 $\mathrm{mg} / \mathrm{L} 2,4 \mathrm{D}$ for optimization of regenerative callus. Calli were maintained in dark at $25^{\circ} \mathrm{C}$, and subcultured on fresh medium at one week interval. Later the callus was sub cultured on reduced concentration of callus $2 \mathrm{mg} / \mathrm{L} \mathrm{2,4D}$ and then shifted to regenerative media.

\section{In vitro regeneration}

Induced calli were sub-cultured on MS medium supplemented with $30 \mathrm{~g} / \mathrm{l}$ sucrose, 3 $\mathrm{mg} / \mathrm{l}$ casein hydrolysate and $3 \mathrm{mg} / \mathrm{l}$ proline with the following two different hormonal concentrations for shoot organogenesis 1 to 5 $\mathrm{mg} / \mathrm{l}$ kinetin. For in vitro regeneration calli were maintained on MS medium for 2 weeks at $25^{\circ} \mathrm{C}$ temperature and $16 / 8 \mathrm{~h}$ light and dark cycles on petri plates. Later the Shoots were sub-cultured on the same medium at one week interval to test tubes containing the media.

\section{Multiple shoot induction}

For induction of multiple shoots, MS basal medium containing $30 \mathrm{~g} / 1$ sucrose, $3 \mathrm{mg} / \mathrm{l}$ casein hydrolysate and $3 \mathrm{mg} / \mathrm{l}$ proline supplemented with different concentration of high level of BAP and low concentration of 2 , 4-D was used. The cultures were kept in light at $22 \pm 1 \mathrm{C}$ in $16 / 8 \mathrm{~h}$ of light/dark cycle regime with sub culturing one in two weeks. Counting of multiple shoots was done for each explant after it was sub cultured twice. The main shoots were removed during sub culturing. Shoots which emerged from mature embryos directly without callus interphase were separated and transferred on rooting media.

\section{Rooting and Hardening}

The regenerated plantlets were transferred on MS media containing $0.2 \mathrm{mg} / \mathrm{L}$ IAA for rooting. Regenerated shoots were sub-cultured on half strength MS basal medium solidified with $8 \mathrm{~g} / \mathrm{L}$ agar. For root induction, the shoots were maintained for 7 days at $25^{\circ} \mathrm{C}$ temperature, $16 / 8 \mathrm{~h}$ photoperiod of about 40 $50 \mu \mathrm{E} \mathrm{m}-2 \mathrm{~s}-1$.Plantlets after rooting were hardened in liquid MS basal medium for 4 days. After primary hardening, plantlets were grown in mixture of the soil, peat and vermiculite $(2: 1: 1)$, at $22^{\circ} \mathrm{C}$ under a $16 / 8 \mathrm{~h}$. In the callus induced and direct shoot induction study the number of shoots per explants and percent of regeneration were recorded.

\section{Results and Discussion}

\section{Callus induction and regeneration}

The callus induction was tested on different concentrations $2,4,6 \mathrm{mg} / \mathrm{L}$ of 2,4,D and all tested callus induction media showed variable embryogenic callus induction efficiency in four Indian wheat varieties HD2888, HD2932, DWB148 and DWB88 along with different percentage of precocious germination.

The percent of callus induction with HD28888 showed $99 \%$ callus induction where as HD2932, DBW148 showed 89 and $86 \%$ for mature embryos respectively with $4 \mathrm{mg} / \mathrm{L} \mathrm{2,} \mathrm{4,}$ D. After one subculture of 7days the callus was sub cultured on $2 \mathrm{mg} / \mathrm{L} \mathrm{2,4,D}$ in order to maintain the callus phase and also to induce the regeneration efficiency. The optimum induced callus was showed $99 \%$ regeneration with MS media containing $1 \mathrm{mg} / \mathrm{L}$ kinetin and 2mg/L 2, 4, D. (Table.1; Fig1\&2)

\section{Multiple shoot induction and regeneration}

The effect of different concentrations of 1-3 $\mathrm{mg} / \mathrm{L} \mathrm{BAP}$ alone and $0.5 \mathrm{mg} / \mathrm{L} 2,4$, D was tested. Optimization of multiple shoot induction was carried out to reduce the regeneration time of the wheat as callus induction mediated regeneration will take at least 1 to 2 months. Seven multiple shoots 
was observed after 20 days of incubation at $22^{\circ} \mathrm{C}, 16 / 8 \mathrm{~h}$ light and dark incubation on $1 \mathrm{mg} / \mathrm{L}$ BAP and $0.5 \mathrm{mg} / \mathrm{L} \mathrm{2,4,D}$ and HD2932 showed $100 \%$ of regeneration compared to HD2888 (96\%) and DBW88 (68 \%) varieties. (Table.2:Fig.3). For HD2932 1mg/L BAP and $0.5 \mathrm{mg} / \mathrm{L} \mathrm{2}, 4$, D is sufficient for initiating shoot regeneration. The shoots were sub cultured into shooting media containing $2 \mathrm{mg} / \mathrm{L}$ kinetin and $0.5 \mathrm{mg} / \mathrm{L}$ IAA. After a week of rooting the regenerated wheat was placed onto hardening material and the survived plants were transferred to pots in green house.
Both mature and immature embryos have been used extensively in tissue culture protocols, but mature embryos were found to be a better choice in comparison to immature embryos (Özgen et al. 1998). Immature embryos are better explant source when regeneration is considered, but they require time and growth facilities (Zale et al. 2004) whereas mature embryos are available throughout the year. Mature embryos can either be dissected (Yu et al. 2008) or used directly (Özgen et al. 1998).

Table.1 Different Combination of Growth Regulator in MS Media used for Callus induction and Regeneration.

\begin{tabular}{|c|c|c|c|c|c|}
\hline Wheat Variety & $\begin{array}{l}\text { Concentrati } \\
\text { ons of } 2,4, D \\
\quad(\mathrm{mg} / \mathrm{l})\end{array}$ & $\begin{array}{c}\text { Percent } \\
\text { Induction } \\
(\%)\end{array}$ & $\begin{array}{c}\text { Coml } \\
2,4, D\end{array}$ & $\begin{array}{l}\text { s of } \\
\text { netin }\end{array}$ & $\begin{array}{c}\text { Percent } \\
\text { Regeneration } \\
(\%)\end{array}$ \\
\hline HD2888 & 2 & 95 & 2 & 0.5 & 80 \\
\hline HD2932 & 2 & 86 & 2 & 0.5 & 76 \\
\hline DBW148 & 2 & 60 & 2 & 0.5 & 55 \\
\hline HD2888 & 4 & 99 & 2 & 1 & 100 \\
\hline HD2932 & 4 & 96 & 2 & 1 & 89 \\
\hline DBW148 & 4 & 86 & 2 & 1 & 65 \\
\hline HD2888 & 6 & 75 & 2 & 2 & 85 \\
\hline HD2932 & 6 & 63 & 2 & 2 & 70 \\
\hline DBW148 & 6 & 45 & 2 & 2 & 55 \\
\hline
\end{tabular}

Table.2 Different Combinations of Growth Regulators in MS Media used for Multiple Shoot Induction

\begin{tabular}{|l|c|c|c|c|}
\hline Wheat Variety & $\begin{array}{c}\text { Combinations of BAP and } \\
\mathbf{2 , 4 , D}(\mathbf{m g} / \mathbf{l})\end{array}$ & $\begin{array}{c}\text { Shoot induced } \\
\text { (nos) }\end{array}$ & $\begin{array}{c}\text { Percent } \\
\text { regeneration (\%) }\end{array}$ \\
\hline HD2888 & 1 & 0.5 & 5 & 89 \\
\hline HD2932 & 1 & 0.5 & 7 & 100 \\
\hline DBW88 & 1 & 0.5 & 3 & 68 \\
\hline HD2888 & 2 & 0.5 & 4 & 89 \\
\hline HD2932 & 2 & 0.5 & 5 & 95 \\
\hline DBW88 & 2 & 0.5 & 3 & 48 \\
\hline HD2888 & 3 & 0.5 & 2 & 62 \\
\hline HD2932 & 3 & 0.5 & 2 & 65 \\
\hline DBW88 & 3 & 0.5 & 2 & 54 \\
\hline
\end{tabular}


Fig.1

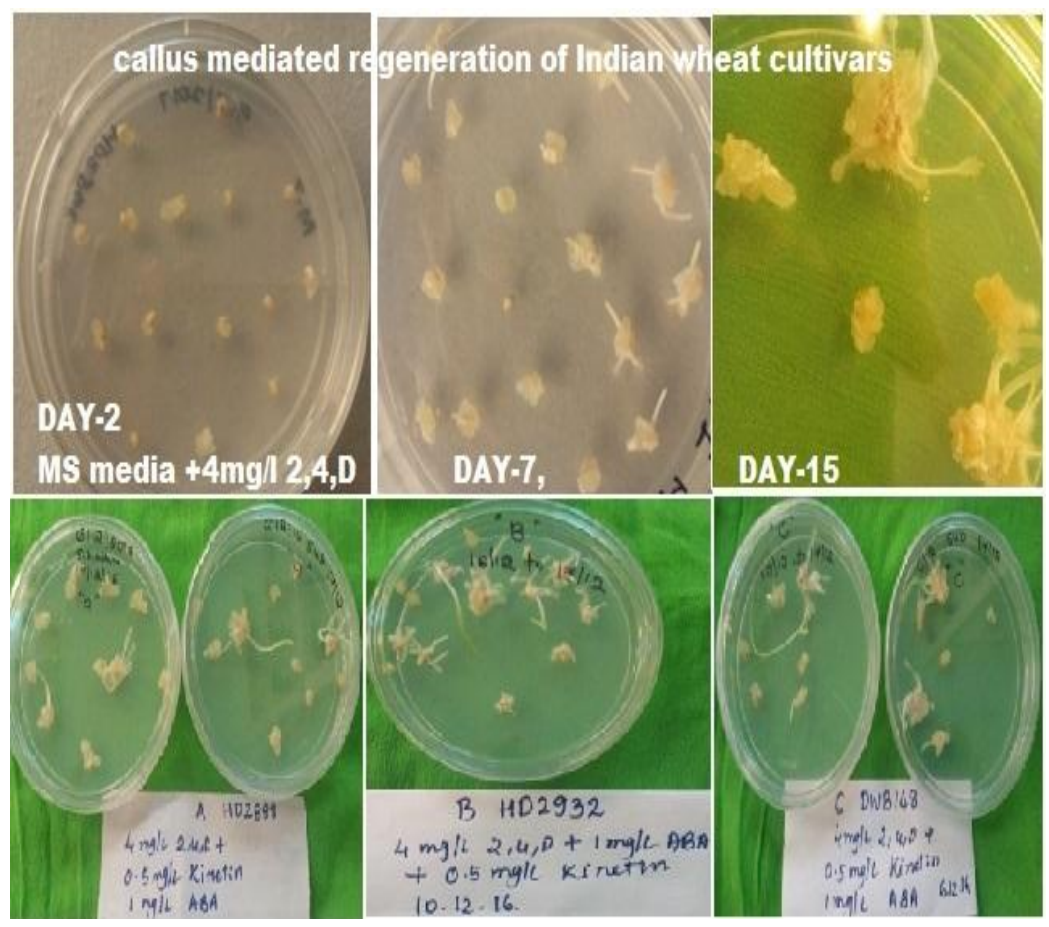

2. Somatic embryogenesis and regeneration of wheat A.HD2888, 3. Embryogenesis and regeneration of wheat HD2888, on MS Medium containing only B.HD2939, C.DWB148 on MS M edium with $1 \mathrm{mg} / \mathrm{L}$ kinetin $1 \mathrm{mgl}$ kinetin
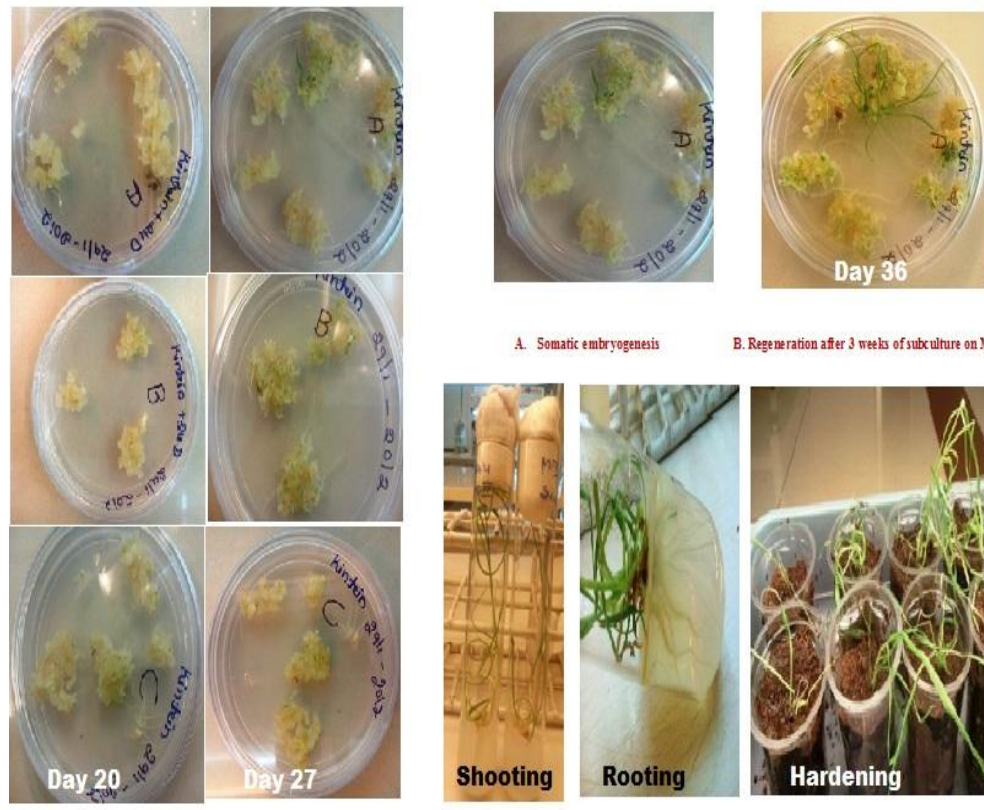

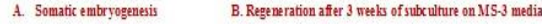
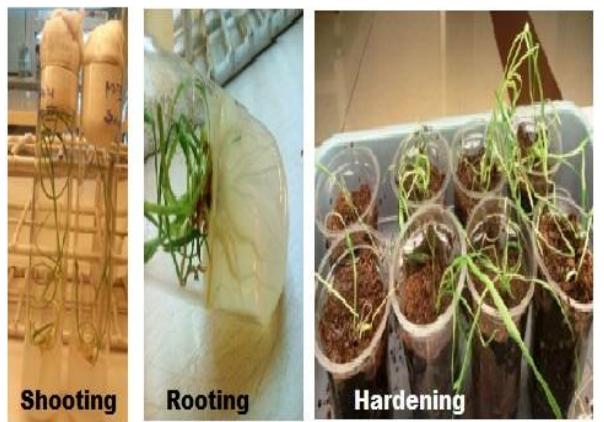


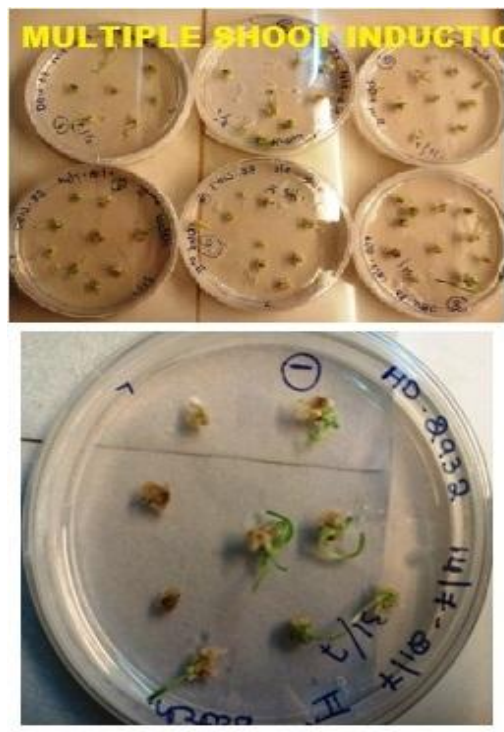

Second step is the optimization of the medium on which maximum plantlets are regenerated. Indole-3-Acetic Acid (IAA), 6BenzylAminoPurine (BAP) and Kinetin were the most extensively used hormones (Haliloglu, 2006). But others can also be used like Thidiazuron (Xueyan et al. 2000). There are several drawbacks associated with these growth regulators such as longer incubation period resulting in the loss of explants viability for regeneration and high cost etc.

The callus is a rapidly proliferating undifferentiated mass of cells, which can be obtained by culturing explants on nutrient media containing specific growth hormones (Naqvi et al., 2002). Media compositionmainly the hormonal balance-is an important factor influencing in vitro culture initiation and plant regeneration from embryos (Jiang et al.,1998) The auxin 2, 4-dichlorophenoxy acetic acid (2, 4-D) alone or in combination with cytokinins, is widely used to enhance callus induction and maintenance (Castillo et al., 1998). In tissue culture of cereals including wheat, 2,4-D is often used for callus induction, and different combinations of auxin such as napthaleneactic acid (NAA) and indoleacetic acid (IAA) and cytokinin were

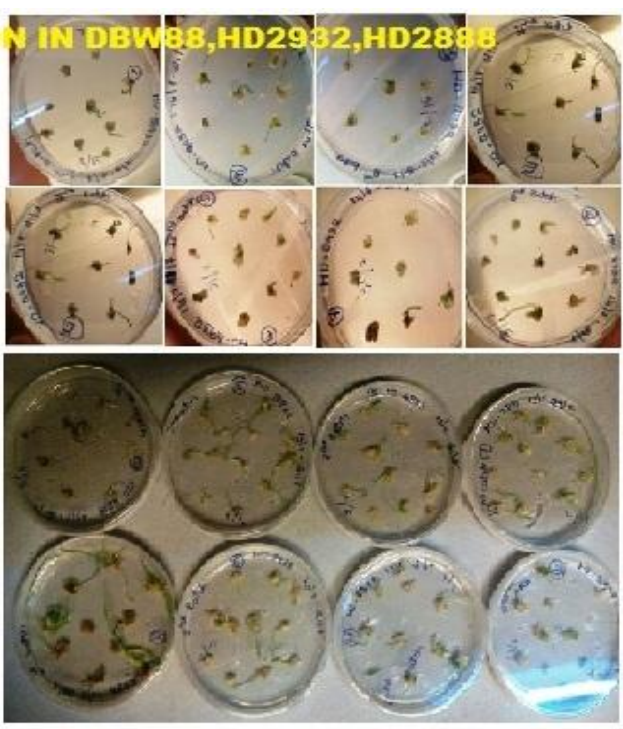

used for stimulating plant regeneration from calli (Bhaskaran et al., 1990).

The present study is on the plant growth promoters which influence on callus induction and regeneration to find out the optimum concentrations using mature embryos in Indian wheat cultivars. Studies have reported the effect of growth regulators on callus induction and regeneration in wheat (Chauhan et al. 2007). But these studies were carried out in limited number of wheat genotypes and with less number of PGR combinations in the media. Earlier reports, claims 2,4-D has optimum callus induction capacity in wheat (Yu et al. 2008). However, our results indicated that $4 \mathrm{mg} / \mathrm{L} \mathrm{2,4-D} \mathrm{has} \mathrm{the} \mathrm{fastest}$ rate of callus induction. Shoot regeneration is another crucial step after callus induction in tissue culture. BAP and kinetin were tested at different concentration and combinations. The absence of 2,4-D in regeneration medium showed the shoot induction as well as the root induction. The root induction suppressed to a large extent by supplying 2,4-D alone in regeneration medium or with other growth regulators, only shoot induction occurred. It was evident that the inclusion of 2,4-D in combination with cytokinins is valuable for regeneration. The present study results 
correlate with Chauhan et al. 2007. Overall, the standardized regeneration showed 100\% regeneration efficiency irrespective of the genotype both by callus mediated and multiple shoot induction by mature embryo as explants.

\section{Acknowledgements}

This work was funded by a grant from University of Agricultural Sciences, Dharwad. First author Dr.Krishnaveni $\mathrm{R}$ is thankful to the University of Agricultural Sciences, Dharwad for a Post-Doctoral Research Fellowship with independent research grant and also to Department of Biotechnology (IABT) University of Agricultural Sciences, Dharwad for providing lab facilities, Dr. Suma S Biradar, AICRP on Wheat, MARS, University of Agricultural Sciences, Dharwad for providing wheat seeds.

\section{References}

Ahmad, A. H. Zhong, Wang, W. Sticklen, M.B. (2002). Shoot apical meristem: In vitro regeneration and morphogenesis in wheat (Triticum aestivum). In Vitro Cell. Dev. Biol. Plant, 38: 163167.

Ahmed, K.Z. Sagi, F. (1993). Culture of and fertile plant regeneration from regenerable embryogenic suspension cell derived protoplasts of wheat (Triticum aestivum L.).-Plant Cell Rep. 12: 175-179.

Alisarali (2013) Genetic transformation of wheat (Triticum aestivum l.) for enhanced thermotolerance, thesis.

Barro, F. Martin, A. Lazzeri, P.A Barcelo, P. (1999) Medium optimization for efficient somatic embryogenesis and plant regeneration from immature inflorescences and immature scutella of elite cultivars of wheat, barley and tritordeum. Euphytica 108(3):161-167.
Becker, D. Brettschneider, R. Lorz, H. (1994) Fertile transgenic wheat from microprojectle bombardment of scutellar tissue. Plant J. 5:299-307;

Benderradji, L, Faical B., Kamel K. Nadia Y. Abdelhamid D. Khaled M. Hamenna Bouzerzour (2012). Callus Induction, Proliferation, and Plantlets Regeneration of Two Bread Wheat (Triticum aestivum L.) Genotypes under Saline and Heat Stress Conditions. International Scholarly Research Network ISRN Agronomy ( 8 )

Bhaskaran, S. Smith, R.H. (1990). Regeneration in cereal tissue culture: a review. Crop sci., 30: 1328-1336

Castillo, A.M., Egafia, B. Sanz J.M. Cistue, L. (1998). Somatic embryogenesis and plant regeneration from barley cultivars grown in spain: Plant cell reports., 17(11): 902- 906.

Chauhan H, Desai SA, Khurana P (2007) Comparative analysis of the differential regeneration response of various genotypes of Triticum aestivum, Triticum durum and Triticum dicoccum. Plant Cell Tissue Org 91:191-199

Debasis, P. Vishnudasan, D. Paramjit, K. (2006).Agrobacterium-mediated transformation of mature embryos of Triticum aestivum and Triticum durum Current science, 91, (3).

Filippov, M.D. Miroshnichenko, D. Vernikovskaya, Dolgov,S (2006). The effect of auxin and exposure to auxin and genotypes on somatic embryogenesis from mature embryos of wheat. Plant cell, tissue and organ cult. (84): 213-222.

Haliloglu, K. (2006). Efficient regeneration system from wheat leaf base segments. Biologia plantarum. 50, 3, 326-330

He, G.Y. and Lazzeri, P.A. (2001). Improvement of somatic embryogenesis and plant regeneration from durum wheat (Triticum turgidum var. Durum 
desf.) Scutellum and inflorescence cultures. Euphytica, 119, 3,369-376.

Jiang, W.C. Myeong-je, lemaux, P.G. (1998). Improved callus quality and prolonged regenerability in model and recalcitrant barley (hordeum vulgare 1.) Cultivars. Plant biotechnology, 15(2): 63-69.

Mamrutha, H.M. Kumar, R. Venkatesh, K. Sharma, P. Kumar R, Tiwari, V. Sharma, I. (2014). Genetic transformation of wheat - present status and future potential. $J$ Wheat Res. 6(2):1-13.

Naqvi, S.M.S. Yasmin, H. Rashid, Z. Chaudary, Qureshi,A (2002). Callus induction from seeds of zea mays var. Ev-2097. Pakistan j. Biol. Sci., 5: 9568.

Ozgen, M. Turet, M. Altinok, S. Sancak, C. (1998). Efficient callus induction and plant regeneration from mature embryo culture of winter wheat (Triticum aestivum.) genotypes. Plant cell reports, 18, 3-4, p. 331-335.

Parmar, S.S. Sainger, M. Chaudhary, D. Jaiwal P.K. (2012). Plant regeneration from mature embryo of commercial Indian bread wheat (Triticum aestivum L.) cultivars. Physiol Mol Biol Plants 18(2):177-183

Rakesh, K. Harohalli, M. Mamrutha, Amandeep K, Karnam V, Anita G, Raj
Kumar, Vinod, T. (2017) Development of an efficient and reproducible regeneration system in wheat (Triticum aestivum L.) Physiol Mol Biol Plants 23(4):945-954

Ren, J.P. Wang, X-G. Yin, J. (2010) Dicamba and sugar effects on callus induction and plant regeneration from mature embryo culture of wheat. Agric Sci China 9(1):31-37

Satyavathi, V.V, Jauhar, P.P, Elias, E.M. and Rao, M.B. (2004). Effects of growth regulators on in vitro plant regeneration in durum wheat. Crop science, 44, 5, 1839-1846.

Yu, Y. Wang, J. Zhu, M.L. and Wei, Z.M. (2008). Optimization of mature embryos based high frequency callus induction and plant regeneration from elite wheat cultivars grown in china. Plant breeding, 127, 3, 249-255.

Zale, Janice, M. Borchardt-wier, Harmony, Kidwell, Kimberly K. Steber, Camille M. (2004) Callus induction and plant regeneration from mature embryos of a diverse set of wheat genotypes. Plant cell, tissue and organ culture. 76, 3. 277-281.

Ziemienowicz A. (2014) Agrobacteriummediated plant transformation: Factors, applications and recent advances. Biocat Agric Biotechnol, 3 (4) 95-102.

\section{How to cite this article:}

Krishnaveni, R., D. P. Biradar, I. S. Katageri and Shuba, S. 2019. Optimization of an efficient rapid regeneration of Indian wheat cultivars by callus induction and multiple shoot induction using mature embryos. Int.J.Curr.Microbiol.App.Sci. 8(12): 1685-1692. doi: https://doi.org/10.20546/ijcmas.2019.812.202 